\section{Hepatotoxicity associated with} herbal tablets

On 29 March 1994 a 69 year old woman who was taking levothyroxine $(0.1 \mathrm{mg} / \mathrm{day})$ and ibuprofen $(400 \mathrm{mg} /$ day) presented to her general practitioner with nausea, pruritus, dark urine, pale stools, and yellow sclerae after six weeks of daily self treatment with 6-15 herbal tablets. These were labelled Venencapsan and industrially prepared for one pharmacy from horse chestnut leaf, milfoil, celandine, sweet clover, milk thistle, and dandelion root with herb. Liver function was abnormal on 14 April but had improved by 2 May (table 1). She was negative for hepatitis $A$ and B. Ultrasonography and computed tomography showed normal bile ducts without signs of obstruction. Her symptoms disappeared after six weeks, and she restarted the herbal tablets but not ibuprofen (she had stopped both while continuing levothyroxine)

On 27 May she was admitted with jaundice and only levothyroxine was continued. There was no evidence of alcohol abuse, and serum tests for hepatitis A, B, and $C$; toxoplasmosis; infectious mononucleosis; and cytomegalovirus infection gave negative results. Tests for autoantibodies gave negative results (nuclear antibodies, mitochondrial antibodies) or weakly positive results (smooth muscle antibodies). Endoscopic retrograde cholangiopancreatography showed a normal choledochal and pancreatic duct. Liver biopsy showed mild portal inflammation and focal areas of mild steatosis, ballooning, and Kupffer cell hyperplasia. Recovery was uneventful, and by January 1995 her liver function had returned to normal (table 1).

The herbal tablets are more suspect in this case than ibuprofen, because ibuprofen had been taken regularly over the past decade and was not restarted after the first episode. Analysis of the tablets did not show pharmaceuticals or pyrrolizidine alkaloids, and it remains unclear which constituent(s) might have been responsible. Horse chestnut leaf has been associated once with hepatitis after intramuscular administration. ${ }^{1}$ Medicinal use of sweet clover can provide up to $30 \mathrm{mg}$ of coumarin per day, ${ }^{2}$ and this plant lactone has hepatotoxic potential in daily doses of $25 \mathrm{mg}$ or more. ${ }^{3}$ However, we recovered only $0.1 \mathrm{mg}$ of coumarin per tablet, so our patient was exposed to only 0.6-1.5 mg/day.—P A G M DE SMET, Royal Dutch Association for the Advancement of Pharmacy, the Hague, A J M VAN DEN EERTWEGH, w LESTERHuIs, Merwede Hospital, Dordrecht, B H CH STRICKER, Netherlands Centre for Monitoring Adverse Reactions to Drugs, Rijswijk, Netherlands

1 Takegoshi K, Tohyama T, Okuda K, Suzuki K, Ohta G. A case of Venoplant-induced hepatic injury. Gastroenterologia faponica hepatic injury.

2 Bisset NG, ed. Herbal drugs and phytopharBisset NG, ed. Herbal drugs and phytophar-
maceuticals. A handbook for practice on a scientific basis. Stuttgart: Medpharm Scientific, 1994:326-8

3 Cox D, O'Kennedy R, Thornes RD. The rarity of liver toxicity in patients treated with coumarin (1,2-benzopyrone). Hum Toxicol 1989;8:501-6.

\section{Rapidly reversible increase in} insulin requirement with interferon

We report a case of a 66 year old man with maturity onset diabetes who developed a rapidly reversible increase in insulin requirement while receiving interferon alfa $2 \mathrm{a}$ for hepatitis C.

The patient's diabetes had been well controlled for three years on a total of 62 units of Mixtard daily (glycosylated haemoglobin $7-9 \%$ ) His other medications were spironolactone $100 \mathrm{mg}$ twice daily and bumetanide $1 \mathrm{mg}$ daily.
Table 1-Results of liver function tests after herbal tablets

\begin{tabular}{|c|c|c|c|c|c|c|}
\hline & \multicolumn{5}{|c|}{ Date of test } & \multirow{2}{*}{$\begin{array}{l}\text { Upper } \\
\text { limit of } \\
\text { norma }\end{array}$} \\
\hline & $\begin{array}{l}14 \\
\text { April }\end{array}$ & $\stackrel{2}{\text { May }}$ & $\begin{array}{l}31 \\
\text { May }\end{array}$ & $\begin{array}{l}17 \\
\text { June }\end{array}$ & $\begin{array}{c}9 \\
\text { January }\end{array}$ & \\
\hline $\begin{array}{l}\text { Total bilirubin ( } \mu \mathrm{mol} / \mathrm{l}) \\
\text { Alkaline phosphatase }\end{array}$ & 27 & 10 & 80 & 50 & 8 & 17 \\
\hline & 229 & 179 & 250 & 142 & 79 & 100 \\
\hline $\begin{array}{l}\text { (U/1) } \\
\text { Aspartate } \\
\text { aminotransferase } \\
\text { (U/I) }\end{array}$ & 47 & 65 & 106 & 29 & 18 & 40 \\
\hline $\begin{array}{l}\text { Alanine } \\
\text { aminotransferase(U/I) } \\
\text { Lactate }\end{array}$ & 244 & 164 & 1004 & 159 & 16 & 30 \\
\hline $\begin{array}{l}\text { Lactate } \\
\text { dehydrogenase } \\
\text { (U/l) }\end{array}$ & 349 & 273 & 545 & 290 & 202 & 320 \\
\hline
\end{tabular}

Table 1-Liver function values during and after treatment with interferon alfa for hepatitis $C$

\begin{tabular}{|c|c|c|c|c|}
\hline \multirow{2}{*}{$\begin{array}{l}\text { Laboratory results } \\
\text { (normal range) }\end{array}$} & \multicolumn{3}{|c|}{ Time after introduction } & \multirow{2}{*}{$\begin{array}{c}5 \text { months } \\
\text { after } \\
\text { withdrawa }\end{array}$} \\
\hline & 2 weeks & 3 months & 6 months & \\
\hline Albumin (36-52 g/l) & 32 & 36 & 35 & 26 \\
\hline$\gamma$-Glutamyltransferase & 39 & 36 & 47 & 22 \\
\hline $\begin{array}{l}\text { Alanine aminotransferase } \\
\quad(5-40 \mathrm{IU} / \mathrm{l})\end{array}$ & 33 & 41 & 24 & 24 \\
\hline $\begin{array}{l}\text { Aspartate } \\
\text { aminotransferase } \\
(10-35 \mathrm{IU} / \mathrm{l})\end{array}$ & 49 & 41 & 35 & 27 \\
\hline Bilirubin $(3-20 \mu \mathrm{mol} / \mathrm{l})$ & 58 & 59 & 36 & 40 \\
\hline $\begin{array}{l}\text { Alkaline phosphatase } \\
(60-300 \mathrm{IU} / \mathrm{l})\end{array}$ & 176 & 247 & 247 & 175 \\
\hline
\end{tabular}

After three months of treatment with interferon alfa, $5000000 \mathrm{U}$ subcutaneously three times weekly, his blood glucose concentration was $50.4 \mathrm{mmol} / \mathrm{l}$, necessitating a progressive increase in his insulin dose. After six months of interferon treatment he was admitted to hospital with vomiting, anorexia, and dehydration. He was then receiving a total of 118 units of Mixtard daily. Interferon was discontinued, as there was no change in his liver function values during treatment (table 1). Within eight days his insulin requirement had fallen to 24 units Mixtard daily. Subsequent follow up showed only a modest increase in insulin requirement to 28 units Mixtard daily.

Autoimmune phenomena during treatment with interferon alfa are well recognised. Development of insulin dependent diabetes with seroconversion for islet cell antibodies during interferon alfa therapy for hepatitis $\mathrm{C}$ has been reported. during treatment with interferon alfa has also been shown in healthy subjects $^{2}$ and in a patient with However, impaired glucose tolerance chronic hepatitis $\mathrm{B}^{3}$; in these cases an autoimmune mechanism is less likely.

To our knowledge this is the first reported case of an increase in insulin requirement associated with interferon alfa therapy which was rapidly reversible on withdrawal of interferon. This suggests that impaired glucose tolerance rather than an the increase. We recommend that in patients with chronic liver disease and diabetes or impaired glucose tolerance interferon alfa should be used with caution and blood glucose monitored regularly.-STEWART CAMPBELL, E H MCLAREN, B I DANESH, Department of Medicine, Stobhill NHS Trust, Glasgow G21 3UW

1 Fabris P, Floreani A, De Lazzari F, Betterle C, Greggio NA, Naccarto R, et al. Development of type I diabetes mellitus durin interferon alpha therapy for chronic HCV hepatitis. Lancet 1992;340:548. of interferon on glucose tolerance and insulin sensitivity. Diabetes 1989;38:641-7. Lopes EPA, Olivera PM, Silva AE, Ferraz
ML, Costa CHRM, Miranda W, et al. ML, Costa CHRM, Miranda W, et al.
Exacerbation of type 2 diabetes mellitus during interferon alfa therapy for chronic hepatitis B. Lancet 1994;343:224. autoimmune phenomenon explained

2 Koivisto VA, Cantell K, Pelkonen R. Effect

\section{ONE HUNDRED YEARS AGO}

\section{TREATMENT OF LIGHTNING STROKE.}

Professor Oliver Lodge writes to the Liverpool Post to warn the public against the notion that a lightning stroke is necessarily fatal. It stops the vital organs, he says, but it rarely destroys them. If respiration can be maintained artificially for a sufficient time, there is a fair chance that the heart will resume its suspended action, and that the stricken man will recover. The practical outcome of this is never to pronounce a lightning-struck person dead until the well-known method of resuscitation from drowning has been practised upon the apparent corpse for two or three hours. Experience has justified this teaching both in America and in France, where it has been strenuously urged and practised by Dr. d'Arsonval. This is a matter of great importance. Comparatively few people are killed by lightning in this country, but it seems probable enough, if we are to believe Professor Lodge, that the number could be still further reduced if artificial respiration were practised. 